\title{
Customer Attitude towards E-Banking Technology with Special Reference to Barnala District of Punjab
}

\author{
Shubham Bansal \\ Department of Commerce and Management Studies Aryabhatta Group of Institutes, Barnala
}

\begin{abstract}
Technology innovations are having significantly importance in human life in general and in professional life in particular. The quick expansion of information technology has refined the life of millions of people. Banking is no exception these days. Considering the growing customer expectations at present time, banks and other financial institutions have incorporated online and mobile banking technology to ease customer's efforts. Innovations such as E-Banking technology have changed the critical structure of all banking system by lowering transaction cost. New E-Banking technology applications are used in mobile phones to check account balances, alerts and conduct other banking activities. The present study is based on to identify the factor affecting the Customer Attitude towards E-Banking Technology. One of the most important changes in the banking industry has been the customer movement from traditional branch banking to electronic banking such as E-Banking.
\end{abstract}

Index Terms: Mobile Banking, Internet Banking, ATM Services.

(C) 2017 Published by MECS Publisher. Selection and/or peer review under responsibility of the Research Association of Modern Education and Computer Science.

\section{Introduction}

Internet banking is easy reliable and convenient way to fulfill our banking needs. This Robert banking facility connects us with our banking at our convenience; we don't have to plan our day according to bank hours, no more waiting in queue. In this method, customer gets his bank account ID and Password and he or she can check his account, pay bill and print receipt through home personal computer, mobile etc which is connect with internet. E-Banking is development of today banking system. It refers to the provision of electronic banking services via internet through personal computer (PC) or any other device with internet capabilities.

From an economic standardization in communications and internal administration increasing customer

* Corresponding author. Tel.:

E-mail address: 
convenience and functionally and reducing cost in back office and front desk banking functions. Internet banking gives customer the ability to access virtually any type of banking services in any place and time. Today technology has become an increasingly viral element in the competitive landscape of the financial service industry. The recent developments have created a totally new service concept and service environment. The emergence of the internet has a significant impact on the diffusion of electronic banking.

The present study has made an attempt to identify the customer attitude towards E-Banking services in the Punjab State by analyzing the sample of 100 customers. The factor analysis technique with rotated method was employed in order to extract the important factor (variables).

\section{Review of Literature}

(1) M. Abdul Hakeem and Y. Moydheen Sha (2015) in their analysis it was observed that majorly influenced factors such as convenience and responsiveness.

(2) Vandana Tandon Khanna \& Neha Gupta (2015) Shows that the factors such as Technology acceptability, safety, availability, user friendliness and accessibility highly depend on the demographic characteristics.

(3) Tavishi and Santosh Kumar (2013) An Empirical Study on Technology Adoption of internet banking Influences of Perceived usefulness, perceived ease of use and perceived risk.

(4) Sabita Paul (2013) The Adoption of Electronic Banking like prompt technological revolution by the customer.

(5) Neena Brar \& Jaspreet Singh (2012) study reveals that the perception of the consumers can be changed and made positive by friendly usage, fewer charges, and proper security.

(6) Rahmath Safeena (2011) factors influencing the Consumer's Adoption of Internet banking investigates the influence of Perceived Usefulness, Perceived Ease of use and Perceived Risk on use of Internet Banking.

(7) Surat Singh (2013) Customer Attitude towards Banking Technology is affected by Technology and Services, Promptness and Accuracy, Technology and Security and Technology and Convenience.

\section{Data and Methodology}

The study is based on primary data which has been collected through close ended questionnaire. The primary data required for the study has been collected from Barnala districts of Punjab State so as to make representatives of entire population. The convenience sampling technique has been used to select this district of Punjab. The sample size of 100 customers has been taken from among the population of who are using banking services. The questions related to socio-demographic characteristics such as gender, education level were also incorporated. The factor analysis technique with rotated method was employed in order to extract the important factors from a list of 10 continues variables which have been given below table-1. From this we designed a questionnaire to solicit customer's views on a five point scale, where 1= Strongly Agree, 2= Agree, 3=Neutral, $4=$ Disagree, $5=$ Strongly Disagree. The 17 version of SPSS has been used to analyze the collected data. 
Table 1.

\begin{tabular}{|l|l|}
\hline S. No. & Variables used for factor analysis \\
\hline $\mathbf{1}$ & My bank service cost is minimum. \\
\hline $\mathbf{2}$ & Feel safe and secure while using my bank's technology. \\
\hline $\mathbf{3}$ & My bank service is fast and error free. \\
\hline $\mathbf{4}$ & The behavior of my bank staff is good. \\
\hline $\mathbf{5}$ & My bank's service timing is saving to me. \\
\hline $\mathbf{6}$ & Easy to use my bank technology. \\
\hline $\mathbf{7}$ & My bank's technology is personalized. \\
\hline $\mathbf{8}$ & The risk associated with my bank's technology is low. \\
\hline $\mathbf{9}$ & The technology of my bank is reliable. \\
\hline $\mathbf{1 0}$ & My bank is easily accessible. \\
\hline
\end{tabular}

\section{Data Analysis and Interpretation}

Table 2. Sample Demographic Characteristics

\begin{tabular}{|c|c|c|}
\hline Gender & Frequency & Percentages \\
\hline Male & 71 & 71.0 \\
\hline Female & 29 & 29.0 \\
\hline Total & 100 & 100.0 \\
\hline \multicolumn{3}{|l|}{ Age } \\
\hline Less than 20 & 14 & 14.0 \\
\hline $21-25$ & 53 & 53.0 \\
\hline $26-30$ & 17 & 17.0 \\
\hline $31-35$ & 11 & 11.0 \\
\hline More than 35 & 5 & 5.0 \\
\hline Total & 100 & 100.0 \\
\hline \multicolumn{3}{|l|}{ Education Level } \\
\hline Metric & 2 & 2.0 \\
\hline Secondary & 12 & 12.0 \\
\hline Graduation & 57 & 57.0 \\
\hline Post Graduation & 29 & 29.0 \\
\hline Total & 100 & 100.0 \\
\hline \multicolumn{3}{|c|}{ Types of Accounts } \\
\hline Savings Account & 85 & 85.0 \\
\hline Current Account & 15 & 15.0 \\
\hline Total & 100 & 100.0 \\
\hline \multicolumn{3}{|c|}{ Category of Banks } \\
\hline Private Banks & 55 & 55.0 \\
\hline Public Banks & 45 & 45.0 \\
\hline Total & 100 & 100.0 \\
\hline
\end{tabular}


The study is revels that 71 percent respondents are male and 29 are female. About 67 percent respondents have average age is 25 or lower than 25 and 33 percent respondents are More than 25 . Then respected to education level which is about 2 percent respondents are metric, 12 is secondary, 57 is graduation, 29 is post graduation. Then types of accounts which is about 85 percent has savings account and 15 has current account. About 55 percent respondents have account in private banks and 45 have account in public banks.

\section{Empirical Results}

Factor analysis technique has been used to obtain the empirical result. Factor analysis technique has been used to fins a small number of factors from large number of variable which are capable of explaining the observed variance in the large number of variables. There are some steps in factor analysis like:

(1) First, a correlation matrix is generated for all the variables.

(2) Second, factors are extracted from the correlation matrix based on the correlation coefficients of the variables.

(3) Third, the factors are rotated in order to maximize the relation between the variables and some of the factors.

Table 3. Descriptive Statistics

\begin{tabular}{|l|l|l|l|}
\hline & Mean & Std. Deviation & N \\
\hline My bank service cost is minimum. & 2.17 & .711 & 100 \\
\hline Feel safe and secure while using my bank's technology. & 2.17 & .667 & 100 \\
\hline My bank service is fast and error free. & 1.98 & .635 & 100 \\
\hline The behavior of my bank staff is good. & 2.06 & .736 & 100 \\
\hline My bank's service timing is saving to me. & 2.06 & .633 & 100 \\
\hline Easy to use my bank technology. & 1.99 & .595 & 100 \\
\hline My bank's technology is personalized. & 2.00 & .711 & 100 \\
\hline The risk associated with my bank's technology is low. & 2.29 & .743 & 100 \\
\hline The technology of my bank is reliable. & 1.86 & .586 & 100 \\
\hline My bank is easily accessible. & 1.97 & .577 & 100 \\
\hline
\end{tabular}

The study is revels that the mean, standard deviation and number of respondents who participated in the survey. From descriptive statistics two can conclude that the variable, 'The Risk associated with my bank's technology is low, My bank service cost in minimum and feel safe and secure while using my bank's technology' has the highest mean of 2.29, 2.17 and 2.17.

Table 4. Correlation Matrixes

\begin{tabular}{|c|c|c|c|c|c|c|c|c|c|c|}
\hline & VAR 01 & 02 & 03 & 04 & 05 & 06 & 07 & 08 & 09 & 10 \\
\hline VAR 01 & 1.000 & .194 & .365 & .308 & .134 & .291 & .060 & .020 & .203 & .111 \\
\hline 02 & .194 & 1.000 & .651 & .287 & .358 & .386 & .170 & .246 & .397 & .302 \\
\hline 03 & .365 & .651 & 1.000 & .283 & .279 & .347 & .179 & .291 & .345 & .329 \\
\hline 04 & .308 & .287 & .283 & 1.000 & .252 & .325 & .212 & .208 & .324 & .361 \\
\hline 05 & .134 & .358 & .279 & .252 & 1.000 & .351 & .135 & .178 & .213 & .199 \\
\hline 06 & .291 & .386 & .347 & .325 & .351 & 1.000 & .287 & .075 & .170 & .235 \\
\hline 07 & .060 & .170 & .179 & .212 & .135 & .287 & 1.000 & .153 & .145 & .074 \\
\hline 08 & .020 & .246 & .291 & .208 & .178 & .075 & .153 & 1.000 & .187 & .138 \\
\hline 09 & .203 & .397 & .345 & .324 & .213 & .170 & .145 & .187 & 1.000 & .346 \\
\hline 10 & .111 & .302 & .329 & .361 & .199 & .235 & .074 & .138 & .346 & 1.000 \\
\hline
\end{tabular}

Determinant $=0.120$

The study is revels that the value of the determinant of the correlation matrixes is 0.120 . This is fit for factor 
analysis. Thus; we proceed to the factor analysis. The value of the determinant should be at least 0.000001 for the factor analysis. The value of the determinant in our study is 0.120 allow us to carry with factor analysis. The value of the determinant is greater than 0.000001 shows that there is no problem for the data reduction method in the study. In other words if at least 33 percent of the correlation coefficients are positive then we can say that correlation among the variables are positive.

Table 5. KMO and Bartlett's Test

\begin{tabular}{|l|l|l|}
\hline \multicolumn{2}{|l|}{ Kaiser-Meyer-Olkin Measure of Sampling Adequacy. } & 0.771 \\
\hline Bartlett's Test of Sphericity & Approx. Chi-Square & 201.338 \\
\cline { 2 - 3 } & Df & 45 \\
\cline { 2 - 3 } & Sig. & 0 \\
\hline
\end{tabular}

1) The KMO measures the sampling adequacy test which should be greater than 0.500 for a satisfactory factor analysis to proceed. In our study, this value is 0.771 which allow us to proceed for factor analysis.

2) Bartlett's test is another measure of the strength of the relationship among variables. We would like to reject this null hypothesis, because for data reduction, But in our study test value is less than 0.05 thus we can proceed for data reduction.

Table 6. Communalities

\begin{tabular}{|c|c|c|}
\hline & Initial & Extraction \\
\hline My bank service cost is minimum? & 1 & 0.644 \\
\hline Feel safe and secure while using my bank's technology? & 1 & 0.582 \\
\hline My bank service is fast and error free? & 1 & 0.585 \\
\hline The behavior of my bank staff is good? & 1 & 0.406 \\
\hline My bank's service timing is saving to me? & 1 & 0.344 \\
\hline Easy to use my bank technology? & 1 & 0.65 \\
\hline My bank's technology is personalized? & 1 & 0.665 \\
\hline The risk associated with my bank's technology is low? & 1 & 0.607 \\
\hline The technology of my bank is reliable? & 1 & 0.495 \\
\hline My bank is easily accessible? & 1 & 0.458 \\
\hline
\end{tabular}

The study is revels that how much of the variance in the variables has been accounted for the extracted variables (factors). In our study about 66 percent of the variance in the variables, my bank's technology is 
personalized and 65 percent of the variance in the variables, the easy to use my bank technology is accounted for extracted factors and so on, as shown in the table- 6 given above.

Table 7. Total variance Explained

\begin{tabular}{|c|c|c|c|c|c|c|c|c|c|}
\hline \multirow{2}{*}{$\begin{array}{l}\text { Comp } \\
\text { onents }\end{array}$} & \multicolumn{3}{|c|}{ Initial Eigen-values } & \multicolumn{3}{|c|}{ Extraction Sum of Squared Loadings } & \multicolumn{3}{|c|}{ Rotation Sum of Squared Loadings } \\
\hline & Total & $\%$ Variances & Cumulative $\%$ & Total & $\%$ Variances & Cumulative \% & Total & $\%$ Variances & Cumulative\% \\
\hline 1 & 3.342 & 33.416 & 33.416 & 3.342 & 33.416 & 33.416 & 2.613 & 26.128 & 26.128 \\
\hline 2 & 1.065 & 10.646 & 44.063 & 1.065 & 10.646 & 44.063 & 1.704 & 17.044 & 43.172 \\
\hline 3 & 1.030 & 10.297 & 54.360 & 1.030 & 10.297 & 54.360 & 1.119 & 11.188 & 54.360 \\
\hline 4 & .920 & 9.198 & 63.558 & & & & & & \\
\hline 5 & .863 & 8.631 & 72.189 & & & & & & \\
\hline 6 & .780 & 7.798 & 79.987 & & & & & & \\
\hline 7 & .677 & 6.770 & 86.757 & & & & & & \\
\hline 8 & .525 & 5.249 & 92.006 & & & & & & \\
\hline 9 & .506 & 5.060 & 97.065 & & & & & & \\
\hline 10 & .293 & 2.935 & 100.000 & & & & & & \\
\hline
\end{tabular}

The study is revels that the Eigen value associated with each linear component (factor) before extraction, after extraction and after rotation, before extraction SPSS had identified 10 linear components within the data set. In our study before extraction the Eigen value in terms of percentage of the variance explained about 33.41 percent of the total variance. SPSS extract all factors with Eigen values greater than 1, which leaves us with three factors, before rotation, factor 1 accounted for considerably more variance than other remaining two (33.41\% compared to 10.64 and $10.29 \%$ ) But after extraction it accounts for 26.12 of variance compared to 17.04 and $11.18 \%$ ) in the given table above that about $54.36 \%$ of the total variance has been explained the three factors extracted and all other remaining factors are not significant.

Table 8. Rotated Component Matrix

\begin{tabular}{|c|c|c|c|}
\hline & \multicolumn{3}{|c|}{ Component } \\
\hline & 1 & 2 & 3 \\
\hline My bank service cost is minimum? & & & 0.723 \\
\hline Feel safe and secure while using my bank's technology? & 0.685 & & \\
\hline My bank service is fast and error free? & 0.697 & & \\
\hline The behavior of my bank staff is good? & 0.503 & & \\
\hline My bank's service timing is saving to me? & & & \\
\hline Easy to use my bank technology? & & 0.671 & \\
\hline My bank's technology is personalized? & & 0.801 & \\
\hline The risk associated with my bank's technology is low? & & & -0.596 \\
\hline The technology of my bank is reliable? & 0.703 & & \\
\hline My bank is easily accessible? & 0.674 & & \\
\hline
\end{tabular}

Extraction Method: - Principal Component Analysis.

Rotation Method: - Varimax with Kaiser Normalization.

There are several things to consider about the format of this matrix. First factor consider less than 0.5 have not been displayed because we asked for these factors to be suppressed. 
Using the factor loadings, the banking attributes were grouped into their respective factors and were named according to collective representation. The main findings of the study have been summarized as follows:

\section{Factor 1}

First factor consist of five variables, feel safe and secure while using my bank's technology (0.685), My bank service is fast and error free (0.697), the behavior of my bank staff is good (0.503), the technology of my bank is reliable (0.703) and my bank is easily accessible is (0.674) factors loading. The total variance explained by factor 1 is 33.41 percent. This is named as 'Technology, Promptness, reliable and accessible'.

\section{Factor 2}

Second factor consist of two variables, Easy to use my bank technology (0.671), my bank's technology is personalized (0.801) factor loadings. The total variance explained by factor 2 is 10.64 percent. This is named as 'Technology and Personalized'.

\section{Factor 3}

Third factor consist of two variables, my bank service cost is minimum (0.723), the risk associated with my bank's technology is low (0.596) factor loadings. The total variance explained by factor 3 is 10.29 percent. This is named as 'Technology and Services'.

\section{Conclusion}

The present study is based on to identify the factor affecting the Customer Attitude towards E-Banking Technology. The primary data required for the study has been collected from Barnala districts of Punjab State so as to make representatives of entire population. The convenience sampling technique has been used to select this district of Punjab. The sample size of 100 customers has been taken from among the population of who are using banking services. The 71 percent respondents are male and 29 are female. About 67 percent respondents have average age is 25 or lower than 25 and 33 percent respondents are More than 25 . Then respected to education level which is about 2 percent respondents are metric, 12 is secondary, 57 is graduation, 29 is post graduation. Then types of accounts which is about 85 percent has savings account and 15 has current account. About 55 percent respondents have account in private banks and 45 have account in public banks. The 17 version of SPSS has been used for analysis purpose.

The factor analysis technique has been used and the factor analysis using principle component extraction method with varimax rotation has extracted three factors which explained the 54.36 percent of the total variance. First factor consist of five variables, feel safe and secure while using my bank's technology (0.685), My bank service is fast and error free (0.697), the behavior of my bank staff is good (0.503), the technology of my bank is reliable (0.703) and my bank is easily accessible is (0.674) factors loading. The total variance explained by factor 1 is 33.41 percent. This is named as 'Technology, Promptness, reliable and accessible'. Second factor consist of two variables, Easy to use my bank technology (0.671), my bank's technology is personalized (0.801) factor loadings. The total variance explained by factor 2 is 10.64 percent. This is named as 'Technology and Personalized'. Third factor consist of two variables, my bank service cost is minimum (0.723), the risk associated with my bank's technology is low (0.596) factor loadings. The total variance explained by factor 3 is 10.29 percent. This is named as 'Technology and Services'. Here we found that a few important factors attracts the customer more in using the bank's technology followed by variable 'My bank service is fast and error free, My bank's technology is personalized and My bank service cost is minimum'. 


\section{Refrences}

[1] M. Abdul Hakeem and Y. Moydheen (2015) A Study towards customer satisfaction of Internet banking services with special reference to Tiruchirappalli district. "International journal on Scientific Research, Issue 5, May-2015, ISSN 2277-8179.

[2] Vandana tendon Khanna and Neha Gupta (2015) Customer perception about banks technology for innovative channels of public banks in India. "International journal of Business and Management" Vol. 10 No. 2, ISSN 1833-3850.

[3] Tavishi and Santosh Kumar (2013) the empirical study Technology adopted by Indian banks, "Global journal of Management and Business Studies, ISSN 2248-9878, Volume 3.

[4] Sabita Paul (2013) The Adoption of Electric banking in Odessa, India “ Journal on International Level About Scientific and Technology Research Volume 2, Issue 5, May 2013, PP No. 258-262.

[5] Rahmath Safeena (2011) Internet Banking Adoption in an emerging Economy "Indian Customer's Outlook" International Arab Journal of E-Technology (IAJE), Vol. 2, No. 1, January 2011, PP No. 56-64.

[6] Surat Singh (2013) Customer Attitude towards Banking Technology "International Journal of Management of Business \& Research" ISSN 2249-2143 No. 2, July-December 2013.

[7] Calisir, F. and Gumussoy, C.A. (2008). "Internet Banking versus other Banking Channels". View of Youth, International Journal of Information Management, Vol. 28, PP.215-221.

[8] Masocha R. N Chiliya and S Zindiye (2011) E Banking adoption by customer in the rural milieus of South Africa: A Study of Alice, Eastern Cape, South Africa. African Journal on Business Management 18571863.

\section{Authors' Profiles}

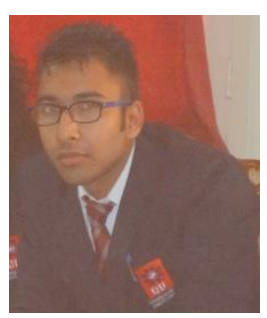

Autho Shubham Bansal is working in Aryabhatta Group of Institutes, Barnala as a Assistant Professor in in Commerce and Management Studies Department since Aug, 2016. I have completed my MBA in Fin Finance and Marketing stream at Chandigarh University, Gharuan (Punjab).

How to cite this paper: Shubham Bansal,"Customer Attitude towards E-Banking Technology with Special Reference to Barnala District of Punjab", International Journal of Education and Management Engineering(IJEME), Vol.7, No.3, pp. 51-58, 2017.DOI: 10.5815/ijeme.2017.03.06 